OPEN ACCESS

Edited by:

Chunfu Zheng,

Fujian Medical University, China

Reviewed by:

Yi-Quan Wu,

National Cancer Institute (NCl),

United States

Kai Huang,

University of Texas Medical Branch at

Galveston, United States

*Correspondence:

Carlos Maluquer de Motes

c.maluquerdemotes@surrey.ac.uk

Specialty section:

This article was submitted to

Molecular Innate Immunity,

a section of the journal

Frontiers in Immunology

Received: 01 June 2020

Accepted: 24 August 2020

Published: 01 October 2020

Citation:

El-Jesr $M$, Teir $M$ and

Maluquer de Motes C (2020) Vaccinia Virus Activation and Antagonism of

Cytosolic DNA Sensing.

Front. Immunol. 11:568412.

doi: $10.3389 /$ fimmu.2020.568412

\section{Vaccinia Virus Activation and Antagonism of Cytosolic DNA Sensing}

\author{
Misbah El-Jesr, Muad Teir and Carlos Maluquer de Motes* \\ Department of Microbial Sciences, University of Surrey, Guildford, United Kingdom
}

Cells express multiple molecules aimed at detecting incoming virus and infection. Recognition of virus infection leads to the production of cytokines, chemokines and restriction factors that limit virus replication and activate an adaptive immune response offering long-term protection. Recognition of cytosolic DNA has become a central immune sensing mechanism involved in infection, autoinflammation, and cancer immunotherapy. Vaccinia virus (VACV) is the prototypic member of the family Poxviridae and the vaccine used to eradicate smallpox. VACV harbors enormous potential as a vaccine vector and several attenuated strains are currently being developed against infectious diseases. In addition, VACV has emerged as a popular oncolytic agent due to its cytotoxic capacity even in hypoxic environments. As a poxvirus, VACV is an unusual virus that replicates its large DNA genome exclusively in the cytoplasm of infected cells. Despite producing large amounts of cytosolic DNA, VACV efficiently suppresses the subsequent innate immune response by deploying an arsenal of proteins with capacity to disable host antiviral signaling, some of which specifically target cytosolic DNA sensing pathways. Some of these strategies are conserved amongst orthopoxviruses, whereas others are seemingly unique to VACV. In this review we provide an overview of the VACV replicative cycle and discuss the recent advances on our understanding of how VACV induces and antagonizes innate immune activation via cytosolic DNA sensing pathways. The implications of these findings in the rational design of vaccines and oncolytics based on VACV are also discussed.

Keywords: STING, CGAS, interferons, antiviral signaling, vaccinia virus (VACV)

\section{INTRODUCTION}

Vaccinia virus (VACV) is the prototypic and the most widely and intensely studied member of the family Poxviridae, a family of cytoplasmic-replicating viruses harboring large $\sim 200 \mathrm{kbp}$ linear dsDNA genomes. VACV is a very immunogenic virus that served as a vaccine for the eradication of smallpox, the only human disease eradicated so far. The virus causing smallpox, variola virus (VARV), and VACV belong to the genus Orthopoxvirus (OPXV), which also includes several other viral species infecting mammals. The origins and evolution of VACV are complex, but likely to share an ancestor with the now extinct horsepox virus (1). Multiple VACV strains exist and were used during the smallpox vaccination campaign around the globe. Although highly similar, the genetic content of these strains may vary, possibly as a reflection of their historical passage and use (2). In 1990, the group of Enzo Paoletti published the genome sequence of VACV strain 
Copenhagen (COP), one of the most studied strains (3). In this review, the COP nomenclature is used to identify VACV genes, but reference is also given to the Western Reserve (WR) strain, which is commonly used as a research tool. Despite the huge potential of using VACV as a vaccine vector for other infectious diseases, the smallpox eradication campaign revealed side-effects and complications derived from the use of live replicationcompetent VACV strains, and highlighted the need for safer vaccines with safety records conforming with current standards. This need fuelled (i) the search for proteins contributing to virulence, and hence likely to attenuate the virus when removed, and (ii) the use of severely attenuated strains generally obtained after serial passages in cell culture. One of this highly attenuated strains is Modified Vaccinia virus Ankara (MVA), a derivative of the Turkish smallpox vaccine strain chorioallantoic VACV Ankara (CVA) that has lost many immunomodulatory and host range genes and is unable to replicate in human cells. The excellent safety profile of MVA and its rapid induction of immune protective responses has fostered its development as vaccine vector against multiple diseases (4). In addition, MVA has become a great tool to understand how VACV is sensed by the host innate immune system, thereby allowing rational improvement of vaccine design.

As a poxvirus VACV is a very complex virus. It follows an exclusively cytosolic replicative cycle, as opposed to most DNA viruses which replicate in the nucleus. Viral genome replication and assembly of nascent virions takes place in specific areas of the cytoplasm generally known as viral factories $(5,6)$. Establishment of viral factories is preceded by genome release and expression of early genes, which occurs inside the viral cores before these are dismantled and the genome becomes permissive for replication (7-10). Once produced nascent virions travel through the Golgi apparatus and mature into a double-membraned form known as extracellular virus (EV). EV mediate viral spread to neighboring cells and are critical to establish infection within an individual $(11,12)$. As the infection progresses, singlemembraned virions known as mature virus (MV) accumulate inside the cytosol and are released upon cell lysis. In the host, VACV infection initiates in skin fibroblasts and proceeds to inflammatory monocytes recruited to the site of infection (13, 14), which can contain infection but also spread the virus through the blood stream. A core set of genes conserved amongst OPXV can be identified in the central part of the linear genome and are mostly involved in viral replication and morphogenesis. These conserved genes render OPXV antigenically similar and generate cross-protection after immunization. On the contrary, the genome termini are rich in accessory genes whose function is to modulate the host immune response and determine host range. Most of these genes are therefore specific to each member of the genus and have sometimes followed clear duplication and speciation events. For instance, VACV is rich in genes coding for proteins that resemble the cellular B-cell lymphoma (Bcl)-2 family despite having minimal sequence conservation amongst them $(15,16)$. Equally, other genus members such as cowpox virus (CPXV) or ectromelia virus (ECTV) are rich in genes coding for proteins containing Ankyrin repeats (17-19). Research on the functions of these proteins indicates strong convergent evolution on suppression of host innate immunity. Most of the VACV immunomodulatory genes are under the control of early promoters and are therefore deployed as soon as infection initiates. Some have been identified into the viral particle and may become immediately available upon entry (20-22). Between one-third and one-half of VACV proteins are estimated to interfere with the host immune response, some by more than one mechanism. Given this arsenal of immunomodulatory proteins it remains puzzling how VACV is such an immunogenic virus and induces potent humoral and cellular responses to self and foreign antigens. A unique property of VACV and poxviruses is to replicate in the cytosol, where most innate pattern recognition receptors (PRR) reside $(23,24)$. The innate immune system provides a rapid and robust response to invading pathogens that is well-known to impact and shape the subsequent adaptive response clearing the infection. The evolutionary interplay between host innate sensors and viral antagonists in the highly hostile cytosolic niche occupied by VACV is likely to profoundly determine the outcome of infection and therapeutic treatment.

Here, we review the current knowledge on how cells sense VACV infection through its DNA genome and how VACV in turn prevents this recognition. VACV produces several intracellular proteins targeting the core components of host DNA sensing signaling and others targeting components acting downstream. VACV also encodes soluble decoy receptors neutralizing some of the host cytokines induced by DNA sensing pathways such as interferons (IFN) and tumor necrosis factor (TNF)- $\alpha$, but these are not covered here and we refer the reader to previous reviews on the topic $(16,25-27)$. Finally, we discuss the implications of VACV DNA sensing in the therapeutic use of VACV as a vaccine vector and oncolytic agent.

\section{OVERVIEW OF ANTIVIRAL CYTOSOLIC DNA SENSING}

The presence of foreign RNA and DNA within the cell cytosol is a clear sign of danger. Intracellular DNA is detected by a number of PRR that lead to a robust cellular response characterized by a rapid production of chemokines and cytokines including type I IFN (IFN-I) and the subsequent expression of IFN-stimulated genes (ISG). Induction of this antiviral response mostly relies on transcriptional activation by IFN responsive factors (IRF) and the nuclear factor $\kappa$-light-chain-enhancer of activated B cells (NF$\kappa \mathrm{B})$, although transcription-independent mechanisms exist. This is the case of the Absent in Melanoma (AIM)-2-like receptors, which initiate the release of the potent inflammatory cytokines interleukin (IL)-1 $\beta$ and IL-18 upon recognition of cytosolic DNA $(28,29)$. Activation of antiviral IRF and NF- $\kappa$ B signaling in response to DNA mostly derive from cytosolic DNA sensors, but also from the membrane-bound Toll-like receptor (TLR)9 which recognizes DNA contained in endosomal vesicles (30, 31). TLR9 expression is mostly restricted to specialized immune cells and it transduces signal via myeloid differentiation primary response 88 (MyD88) to eventually phosphorylate IRF3 and IRF7 $(31,32)$. Amongst cytosolic DNA sensors cyclic GMP-AMP 


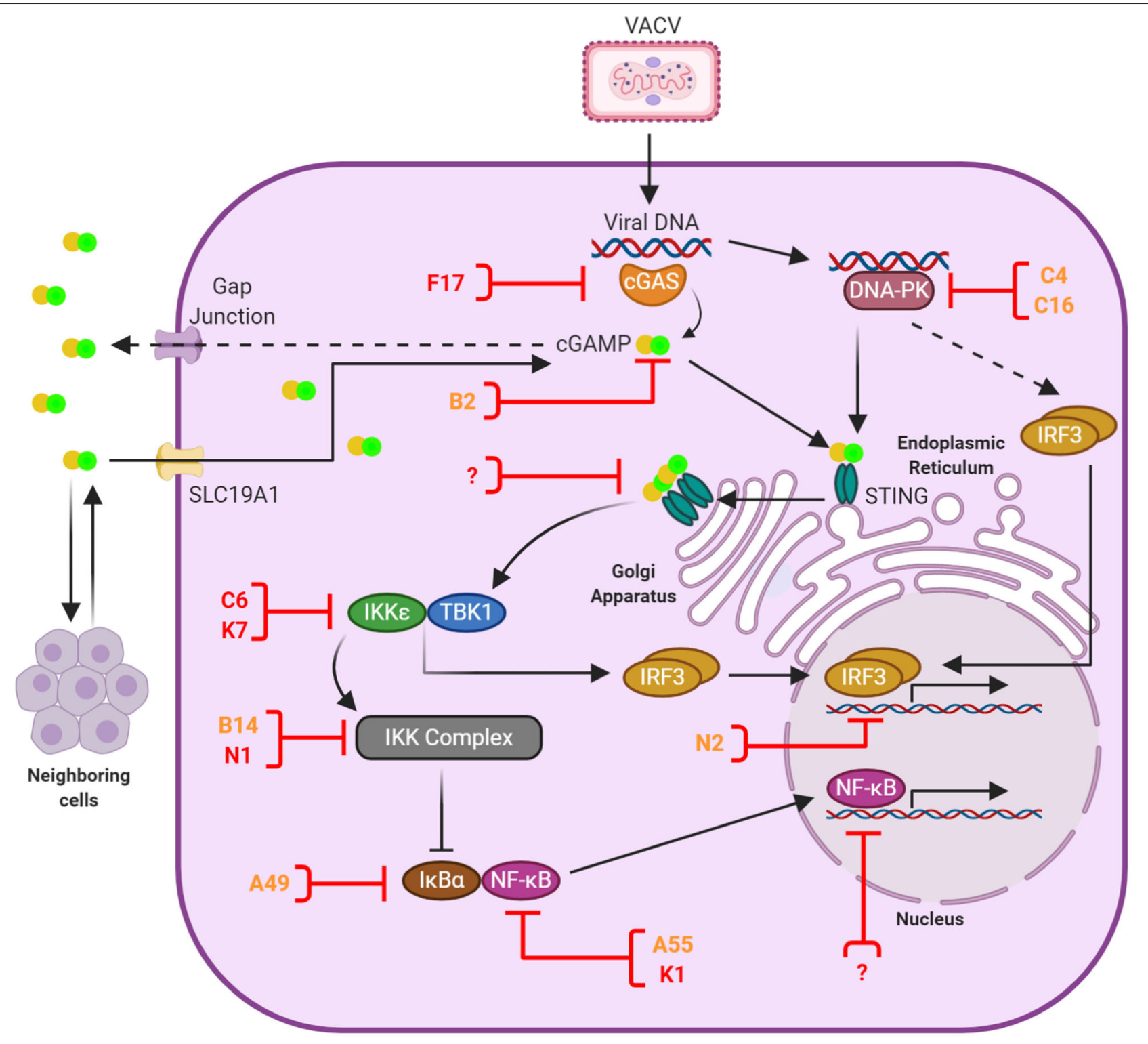

FIGURE 1 | Anti-viral DNA sensing and its antagonism by VACV. Upon infection the VACV genome is released into the cytosol and recognized primarily by cGAS, although other sensors such as DNA-PK play a role in a cell-specific manner. Activated cGAS catalizes the production of $2^{\prime} 3^{\prime}$-cGAMP, which binds and activates STING. In addition, CGAMP is transferred to neighboring cells via gap junctions and imported from the extracellular environment via the transporter SLC19A1. cGAMP-bound STING oligomers mediate the recruitment of TBK1, which subsequently leads to the activation of IRF3 and NF-kB signal transduction and the induction of anti-viral responses. A number of VACV proteins have the capacity to block cytosolic DNA sensing and are shown here in orange or red depending on the level of conservation (see Table 1). These proteins counteract multiple stages of the signaling cascade (shown here with a blocked line). Evidence exists for additional inhibitors acting in the cell nucleus, although they remain yet unidentified. At present no VACV inhibitors of STING have been discovered, but this is a convergent signaling point known to be blocked by several viruses. These potential target sites are indicated with a question mark.

synthase (cGAS) stands out as a critical molecule since it appears essential for IFN production in every setting where this has been tested (Figure 1). cGAS is a DNA-binding enzyme that produces the small second messenger $2^{\prime} 3^{\prime}$-cyclic GMP-AMP (cGAMP) upon recognition of dsDNA (48-52). cGAS belongs to the family of nucleotydiltransferases, loosely related to the oligoadenylates synthetases (53). The unique phosphodiester linkage in cGAMP (the $2^{\prime}-\mathrm{OH}$ of GMP binds to the $5^{\prime}$ of AMP and the $3^{\prime}-\mathrm{OH}$ of
AMP binds to the $5^{\prime}$ phosphate of GMP) confers greater affinity to the stimulator of IFN genes (STING) than other reported cyclic dinucleotides (CDNs) $(51,54,55)$. cGAS patrols the cell cytosol as a sensor for abnormal situations revealed by mislocalised DNA either from invading pathogens or cellular stress (56). Its product cGAMP binds to and activates STING to promote IRF and NF- $\mathrm{kB}$ activation in the stimulated cell (57-60), but also in unstimulated neighbor cells via intercellular and extracellular transfer (61-64). 
Upon cGAMP binding, STING dimers translocate from the endoplasmic reticulum (ER) to Golgi compartments where several post-translational modifications, including palmitoylation and ubiquitylation, take place to establish the STING signalosome (65-68). Here the C-terminal tail of STING interacts with TANK-binding kinase (TBK)-1 to mediate IRF3 activation in a complex trans-phosphorylation process that has recently been enlightened by structural advances (69-71) and has been reviewed in detail elsewhere $(72,73)$. Phosphorylated IRF3 dimerises and translocates to the cell nucleus to drive expression of IRF-dependent genes including the IFN $\beta$ enhanceosome. It is also known that STING oligomerisation induces the subsequent degradation of the inhibitor of $\kappa B$ (ІКB)- $\alpha$ and activate, albeit to a lower extent, NF- $\mathrm{KB}$ responses including the production of TNF $\alpha$, IL- $1 \beta$ and IL-6 (57, 58, 74-76). Canonical NF-кB signaling deriving from cytokine receptors or TLR requires the use of TNF receptor-associated factor (TRAF)- 6 or TRAF2 to activate the IкB $\alpha$ kinase (IKK) complex, which in turn phosphorylates I $\mathrm{K} B \alpha$ and triggers its proteasomal degradation via the E3 ligase $\beta$-TrCP. STING responses require the IKK complex, which can be redundantly activated by TBK1 and its homolog IKKE in a manner that may involve the upstream kinase transforming growth factor- $\beta$-activated kinase 1 (TAK1) $(76,77)$.

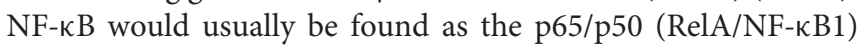
heterodimer, the most common of NF- $\mathrm{\kappa B}$ protein dimers (78). Following the degradation of I $\mathrm{B} \alpha$, NF- $\kappa \mathrm{B}$ becomes free to move from the cytoplasm to the nucleus $(78,79)$. There it can induce the transcription of several target genes, which include immunomodulatory proteins as well as I $\mathrm{B} \alpha$, which is required to maintain a negative feedback loop (80). There also exists a non-canonical pathway, which comes into play during DNA damage. This pathway involves the activity of ataxia telangiectasia mutated (ATM) and poly ADP-ribose polymerase 1 (PARP-1), initiating an outside signal from within the cell that goes through IFN $\gamma$-inducible protein 16 (IFI16) and STING, without the aid of cGAS, and eventually reaches the IKK complex and activates NF- $\mathrm{BB}$ (75).

Before and after the discovery of cGAS other molecules were found to affect DNA sensing signaling. Although the specific biochemical pathways used by these molecules are not always deciphered, nearly all of them converge on STING and may act as cofactors, modulators or regulators of the cGAS-cGAMPSTING axis in a species, cell type and/or self- vs. non-selfspecific manner. This list includes DNA-dependent activator of interferon (DAI) (81), RNA polymerase III $(82,83)$, IFI16 (84), the DExD/H-box helicases DHX9, DDX36 (85) and DDX41 (86); the DNA damage proteins Ku70/80 (87), DNA-PK (88), Mre11 (89) and PQBP1 (90); LSM14A (91); and G3BP1 (92). For a detailed review of this topic, we refer the reader to recent publications $(72,73)$. Two of these molecules, IFI16 and DNAPK, have been reported to have direct roles in VACV sensing and are discussed below in more detail. One of them, namely DNAPK, has been recently implicated in STING-independent IFN-I production in response to DNA and involves the downstream signaling of the heat shock protein HSPA8, in what is being referred to as the STING-independent DNA sensing pathway (SIDSP) (93).

\section{DNA SENSING ACTIVATION IN RESPONSE TO VACV}

Understanding the interplay between host DNA sensing and VACV is difficult because VACV suppresses cell responses through expression of multiple antagonists acting upstream and downstream of these pathways $(16,94)$. Insights are therefore usually gained using attenuated VACV strains such as MVA that have lost most of these antagonists or employing live animal models that can reproduce the complex immunological responses generated upon infection. VACV can cause pathology in commonly used mouse breeds such as Balb/c or C57BL/6, so genetically engineered mice lacking specific DNA sensing and innate immune molecules can provide insights into VACV immunity, with the caveat that DNA sensing in mice may differ from humans as it is becoming increasingly reported $(93,95)$. Inoculation of VACV into transgenic mice deficient for cGAS revealed a mild increase in viral replication and tissue pathology $(14,96)$ that correlated with reduced IFN-I expression, which was also observed in STING deficient mice (14). Similar experiments performed with ECTV, a mouse-specific virus and the causative agent of mousepox, showed enhanced mortality in STING deficient mice (97), but varied susceptibility in cGAS deficient mice $(97,98)$. In contrast, mice lacking IFI204 (the mouse ortholog of IFI16) survived ECTV infection and did not exhibit significant differences in viral replication and viral burden (98). Whilst these studies demonstrated the role of cGAS and STING in mounting responses against VACV and ECTV in vivo, the observed effects were rather mild. This suggests that VACV and ECTV minimize the activity of this pathway to the point that genetic ablation of an already targeted signaling nodule had reduced effect on the overall response. The discovery of viral inhibitors of DNA sensing (discussed below) has allowed a better assessment of the impact of the cGAS-cGAMP-STING axis and recently, ECTV lacking the viral cGAMP nuclease vSchlafen has shown extreme attenuation in multiple models of infection (99). This has revealed the enormous importance of cGAS-STING in poxvirus immunity.

The use of the highly attenuated VACV strain MVA has proven pivotal in understanding DNA sensing immunity against VACV. The MVA genome is significantly shorter than its parental CVA due to five large deletions and additional mutations in at least 25 genes resulting in truncated proteins (100). Since many of these proteins are non-essential immune modulators, it is not surprising that MVA acts as potent inducer of immune responses in most mammalian cells. Before the discovery of DNA sensing pathways, MVA infection was known to be recognized by TLR dependent and independent pathways including the RNA sensor melanoma differentiation-associated protein (MDA)-5 in macrophages and dendritic cells (101-104). MDA5 converges onto IRF3 signaling and IFN-I production via mitochondrial antiviral signaling protein (MAVS) and recognizes long dsRNA in the cytosol $(105,106)$, a by-product of poxviral gene expression in this compartment. Subsequently, several studies have shown that IFN-I induction by MVA relies on cGAS and its downstream adaptor STING $(88,94,107,108)$. Deletion or depletion of cGAS or STING in mouse and human cells results in impaired 
TABLE 1 I VACV proteins counteracting intracellular DNA sensing pathways.

\begin{tabular}{|c|c|c|c|c|c|}
\hline Protein & Size (kDa) & Conservation $^{a}$ & Function & Virulence factor & Key references \\
\hline A49 & 18.7 & Most OPXV & Targets $\beta$-TrCP; NF-кB inhibitor & Yes & $(33,34)$ \\
\hline A55 & 64.6 & Most OPXV & NF-кB inhibitor; prevents NF-кB nuclear translocation & Yes & (35) \\
\hline B2/Poxin & 24.6 & VACV; vSchlafen in OPXV & $2^{\prime}, 3^{\prime}$-cGAMP nuclease & Yes & (36) \\
\hline B14 & 17.3 & Most OPXV & NF-кB inhibitor; targets IKK $\beta$ & Yes & $(37,38)$ \\
\hline C4 & 37.2 & Most OPXV & DNA-PK inhibitor; binds to Ku proteins & Yes & (39) \\
\hline C6 & 17.3 & OPXV & IRF3/7 inhibitor; targets TBK1 adaptors & Yes & $(40)$ \\
\hline C16 & 37.5 & Most OPXV & DNA-PK inhibitor; binds to Ku protein & Yes & $(39,41)$ \\
\hline F17 & 11.3 & OPXV & Dysregulates mTOR; downregulates cGAS and STING & Essential for growth & $(42)$ \\
\hline K1 & 32.4 & OPXV & NF-кB inhibitor; prevents IкB $\alpha$ degradation & Yes & $(43)$ \\
\hline K7 & 17.4 & OPXV & IRF3 inhibitor; targets DDX3 & Yes & $(44)$ \\
\hline N1 & 13.9 & OPXV & NF-кB inhibitor & Yes & $(37,45,46)$ \\
\hline N2 & 20.8 & Most OPXV & Nuclear IRF3 inhibitor & Yes & $(47)$ \\
\hline
\end{tabular}

${ }^{a}$ Conservation within the OPXV is indicated.

induction of IFN $\alpha$, IFN $\beta$, and CXCL10 in response to MVA. These findings are in line with results obtained with other poxviruses and in the context of replicative VACV lacking specific DNA sensing inhibitors $(97,109,110)$. In addition to cGAS other DNA sensors have been implicated in VACV immunity: DNA-PK and IFI16. DNA-PK consists of a heterodimer of the DNA-binding proteins Ku70 and Ku80 and DNA-PKcs, its catalytic subunit. DNA-PK is best known for its role in DNA repair and $\mathrm{V}(\mathrm{D}) \mathrm{J}$ recombination (111), but it also acts as a PRR in response to intracellular DNA (88). DNA-PK leads to IRF3 activation and cytokine production including IFNI in response to cytoplasmic DNA, particularly in fibroblasts. Although the specific biochemical pathway induced by DNA-PK is not as clear as for cGAS, it has been shown to trigger innate immune activation through the cGAS-STING-IRF3 pathway $(88,112)$ and more recently, in a STING-independent manner (93). DNA-PK is essential for cell viability and this limits its genetic manipulation. Nonetheless, murine fibroblasts deficient for specific DNA-PK components show reduced levels of IFNI, CXCL10 and IL-6 when infected with MVA whilst retaining complete responsiveness to RNA virus infection, and this correlated with DNA-PK translocation to viral factories (88). IFI16 has also been shown to translocate to viral factories, particularly in keratinocytes, and this correlated with reduced CCL5 and ISGs production in response to MVA (113), although no difference in IFN-I has been observed in macrophages (107), suggesting a cell-specific role for IFI16 in sensing VACV infection. IFI16 is a critical sensor for nuclear DNA viruses and is actively targeted for immune evasion $(114,115)$. Whilst a VACV inhibitor for IFI16 remains to be discovered, VACV encodes at least 2 molecules preventing DNA-PK-mediated sensing $(39,41)$.

\section{VACV ANTAGONISTS OF DNA SENSING RESPONSES}

VACV employs several strategies to suppress cytosolic DNA sensing. The discovery of these viral inhibitors has served to enlighten these relatively recent innate signaling pathways and provide important insights into their mechanisms of activation and regulation. These inhibitors and strategies are reviewed below and summarized in Table 1 and Figure 1.

\section{Targeting DNA-PK (Proteins C16 and C4)}

The first VACV protein reported to suppress cytosolic DNA sensing during infection was C16, first characterized by Fahy et al. (116). It is a $37.5 \mathrm{kDa}$ non-essential protein comprising 331 amino acids, encoded by the C16L gene (WR010/209), two copies of which are present in the ITRs on both ends of the VACV genome. C16 is highly conserved among some OPVX members such as VARV, ECTV, and CPXV, while in others such as monkeypox virus (MPXV) or camelpox virus (CMLV) the sequence contains disruptions that alter the reading frame (116). Originally, C16 was found to enhance VACV virulence via an unknown mechanism (116). Only later was its role in DNA sensing inhibition revealed as a DNA-PK inhibitor. During VACV infection $\mathrm{C} 16$ binds to the Ku70/80 heterodimer of the DNA-PK complex using its C-terminal domain (41). This prevents the recognition of VACV DNA since the $\mathrm{Ku}$ proteins mediate DNA binding. An engineered VACV lacking $\mathrm{C} 16$ caused less weight loss and induced higher levels of cytokines and chemokines in mice after intranasal inoculation $(41,116)$. Furthermore, MVA, which contains a deletion of 5 amino acids in the Ku-binding domain, induced IFN-I production in a DNA-PK-dependent manner (88). It is worth noting that VACV C16 is a multifunctional protein that has also been shown to manipulate hypoxic signaling and reprogramme energy metabolism $(117,118)$.

More recently, a second VACV protein has been found to target DNA-PK. Protein C4 (WR024) shares 43\% identity with C16; it is highly conserved between several members of the OPXV genus; and it is non-essential for virus growth (119). C4 exhibits a similar function to C16 in regards to DNA sensing inhibition (39). C4 uses its $\mathrm{C}$-terminal region to bind the $\mathrm{Ku}$ proteins and this reduces IRF3 phosphorylation and cytokine induction. Indeed, the binding of both $\mathrm{C} 16$ and $\mathrm{C} 4$ to $\mathrm{Ku} 70$ has been narrowed to three conserved amino acids. Viruses lacking expression of each of these proteins were attenuated in an intranasal model of infection inducing enhanced recruitment 
of immune cells and $\mathrm{T}$ cell activation, but remained as virulent as their parental viruses after intradermal inoculation $(116,119)$. Interestingly, a double deletion virus lacking both C16 and C4 revealed attenuation upon intradermal injection, demonstrating that these proteins had redundant in vivo roles in this model of infection (39). Why VACV devotes three genes (two copies of $\mathrm{C} 16 \mathrm{~L}$ and a copy of $\mathrm{C} 4 \mathrm{~L}$ ) to suppress DNA-PK cytosolic DNA sensing remains unknown, but an explanation might be the high abundance of DNA-PK, particularly in fibroblasts, a primary cell target in the skin. Interestingly, it has been recently shown that DNA-PK can activate a second DNA sensing pathway completely independent of STING activation (93). This could further emphasize the role of $\mathrm{C} 16$ and $\mathrm{C} 4$ in immunomodulation and DNA sensing inhibition given that these proteins may also inhibit SIDSP.

\section{Targeting cGAS (Protein F17)}

Besides the discovery of VACV inhibition of DNA-PK evidence existed that VACV was able to prevent STING activation by other mechanisms (94). One of these was reported by Meade et al. and involved protein F17 (42). F17 (WR056) is a conserved structural protein that constitutes the largest component of the virion lateral bodies and is essential for the formation of infectious virions (120-122). F17 exploits a complex cellular circuit connecting immune sensing and the metabolic rheostat mTOR (mammalian targets of rapamycin). mTOR is composed of two different complex systems, namely mTOR1 and mTOR2, both of which are regulated by distinct subunits conforming a negative feed-back loop $(123,124)$. F17 sequesters the subunits Raptor and Rictor so their regulatory feed-back is disrupted, allowing VACV to usurp mTOR control from the cell. This leads to overactive mTOR that enhances protein synthesis, but also suppresses innate activation at multiple levels including cGAS downregulation by a process that involves Akt (125) and dysregulation of STING vesicles in the ER (42). These effects suppress IRF3 translocation and trigger a potent suppression of ISG induction in both fibroblasts and macrophages, particularly late during infection in agreement with F17 late expression (42, 109). In the absence of F17 VACV infection leads to detectable ISG expression that depend on cGAS, but not IFI16, presence (109), thus supporting the primordial role of cGAS as a poxvirus DNA sensor. Of note, cGAS deletion did not completely abrogate ISG responses in fibroblasts (109), making room for a second IRF3-activating pathway sensing VACV in these cells. The high conservation of F17 not only across OPXV, but also across most vertebrate poxviruses, highlights the fundamental functions of this protein in poxvirus infections.

\section{Targeting cGAMP (Protein B2)}

cGAMP plays a pivotal role in antiviral DNA sensing responses. As a product of activated cGAS it binds STING and triggers innate immune activation in the infected cell. However, it also induces antiviral responses in neighboring cells by multiple mechanisms. cGAMP is transferred to neighboring cells via gap junctions (61) and membrane fusion events (126), is incorporated into exiting viral particles $(127,128)$ and imported into cells from the extracellular milieu via the transporter
SLC19A1 (62, 63). Via these mechanisms cGAMP has the capacity to activate non-infected cells including immune cells and constitutes a potent antiviral signaling molecule. VACV neutralizes the effects of cGAMP by encoding a cGAMP nuclease in gene B2R (WR184), discovered by Eaglesham et al. and named poxvirus immune nuclease (poxin) (36). Poxin was identified in a screen for viruses able to destroy cGAMP, which included 24 viruses belonging to 13 different viral families. Only VACV was found to degrade cGAMP, a reflection of its unique nature as a cytosolic replicating virus, and mass spectrometry confirmed the activity to derive from product B2. Poxin binds and linearises cGAMP cleaving the $3^{\prime}-5^{\prime}$ bond and converting it into linear $\mathrm{Gp}\left[2^{\prime}-5^{\prime}\right] \mathrm{Ap}\left[3^{\prime}\right]$. VACV lacking Poxin shows no defect in growth, but displays a significant reduction of viral titer in mice (36). Homologs of Poxin are found in baculovirus and their insect hosts, perhaps revealing a common origin since insect poxviruses and baculoviruses share ecological niches. Within the Poxviridae, Poxin is not universally conserved and surprisingly in most OPXV it appears as vSchlafen, a fusion of Poxin with a second protein with high similarity to the mammalian family of Schlafen proteins (also known as gene B3R in VACV). Deletion of the entire vSchlafen or only its cGAMP nuclease domain in the context of ECTV renders the virus unable to suppress IRF3 activation during infection and leads to a dramatic 5-log drop in virulence in mice (99), the natural host of ECTV. Despite its critical role in counteracting the antiviral effects of cGAMP both $B 2 R$ and $B 3 R$ are swarmed with inactivating mutations in VARV. Poxin and vSchlafen are early genes, a class of genes expressed from within intact cytoplasmic viral cores (8-10). This allows production of early immune evasion factors before the viral genomic DNA is released and exposed to DNA sensors, and in conjunction with late factors like F17, it ensures complete suppression of innate activation throughout the entire life cycle.

\section{Downstream IRF3 Inhibitors}

Beyond the aforementioned, VACV possesses several different non-essential immunomodulatory proteins, most of which were reported when our knowledge on cytosolic DNA sensing was in its infancy. The discovery of DNA sensing pathways provides now a new dimension to their seemingly redundant roles. In most cases the function of these molecules as DNA sensing modulators has not been formally proven, but when the molecular mechanism of action has been elucidated, their antagonistic role can be anticipated. VACV proteins acting downstream of STING, and therefore expected to antagonize DNA sensing, include protein $\mathrm{C6}$, which acts at the level of TBK1/IKKE. C6 binds to the cellular proteins TANK, NF-кBactivating protein (NAP)-1 and similar to NAP1 TBK1 adaptor (SINTBAD) (40). All three molecules work as adaptors for TBK1 and share a conserved TBK1/IKKE-binding domain (129). TBK1 and its adaptors act as a convergence point for TLRs, RNA and DNA sensing pathways and consistent with this, C6 is able to suppress IFN-I induction in response to poly( $\mathrm{I}: \mathrm{C})$, poly(dA-dT) and RNA virus infection, but did not affect NF$\kappa \mathrm{B}$ activation. VACV lacking C6 expression replicated normally in cell culture, but was significantly attenuated in mice (40). C6 was also shown to suppress IFN-I signaling $(130,131)$. 
Given this multifunctionality C6 becomes an important VACV IFN antagonist and its deletion increases immunogenicity in mice both in the context of virulent and avirulent VACV such as MVA where C6 is not inactivated (132-136). The related VACV protein $\mathrm{K} 7$ also targets the TBK1/IKKE complex to inhibit IRF3 activation. As well as possessing the ability to inhibit NF- $\kappa \mathrm{B}$ activation (137), K7 binds to and inhibits the DEAD-box RNA helicase DDX3, a TBK1 adaptor and substrate required for optimal IRF responses $(44,138)$. K7 binds to the $\mathrm{N}$-terminal region of DDX3 to inhibit its function, ensuring a decreased TBK1/IKK $\varepsilon$-dependent IFN- $\beta$ promoter induction $(44,139)$. Like C6, K7 contributes to VACV virulence in mice and its removal leads to enhanced immunogenicity and memory immune responses $(132,134)$. Finally, the VACV Bcl-2 protein $\mathrm{N} 2$ acts as an IRF3 inhibitor in the nucleus, although its specific target remains elusive (47). N2 is dispensable for virus growth, but contributes to virulence (47), and MVA deleted for gene $\mathrm{N} 2 \mathrm{~L}$ enhances immunogenicity and the immune response to infection, marked by an increase in the production INF- $\beta$ and other pro-inflammatory cytokines immune activation (140).

\section{Downstream NF-кB Inhibitors}

Multiple studies have demonstrated that production of inflammatory cytokines via STING-dependent DNA sensing requires $\mathrm{NF}-\kappa \mathrm{B}$ responses that depend on the IKK complex and the NF- $\kappa \mathrm{B}$ heterodimer. VACV encodes multiple immunomodulators known to suppress NF- $\mathrm{B}$ activation and detailed molecular mechanisms of action exist for several of them (16). VACV protein B14 is a Bcl-2-like protein encoded by the VACV B14R gene that is well-conserved among OPXV such as VARV and CPXV and contributes to virulence $(37,141)$. B14 binds to the $\mathrm{N}$-terminal kinase domain and the scaffolding and dimerisation domain of IKK $\beta$, and prevents its phosphorylation and activation, which in turn prevents the phosphorylation and subsequent degradation of $\operatorname{I\kappa B} \alpha(38,142)$. This interaction is mediated by a surface of B14 that is otherwise utilized for dimerisation $(37,143)$. B14 can also activate the mitogenactivated protein kinase (MAPK)/activator protein 1 (AP-1) pathway (144) and is inactivated in MVA (145), confirming its non-essential role in virus growth. The related VACV protein N1 is a potent virulence factor that serves a dual role as inhibitor of apoptosis and inflammatory signaling $(37,45,46,107,146,147)$. Both functions map to different binding interfaces of the protein (45) and the ability to block NF- $\mathrm{B}$ activation correlates with an impaired CD8 T cell effector and memory response (148). Although its exact mechanism of action for suppressing innate immune activation remains unknown, the inhibitory action of $\mathrm{N} 1$ on NF- $\kappa \mathrm{B}$ signaling is believed to be downstream of the TRAFs. N1 is also known to be modified by ubiquitylation during infection, but this did not affect its ability to suppress NF- $\kappa \mathrm{B}$ activation (149). A third VACV Bcl-2 protein evolved to suppress NF- $\kappa$ B signaling is A49, which contains an N-terminal region that mimics the I $\mathrm{B} \alpha$ degron sequence that mediates its proteasomal destruction $(33,150)$. A49 is phosphorylated by IKK $\beta$ and subsequently recognized by the E3 ubiquitin ligase $\beta$-TrCP, but unlike IкB $\alpha$ it is spared because it lacks the ubiquitin acceptor sites located upstream of the degron $(33,150)$. Using this mechanism A49 binds tightly to $\beta$-TrCP only when IKK $\beta$ is activated and canonical $\beta$-TrCP targets including $\mathrm{I} \kappa \mathrm{B} \alpha$ and $\beta$-catenin accumulate in their phosphorylated forms and are not processed $(33,150,151)$. A49 antagonism of NF-кB contributes to virulence $(33,34)$, but mutant A49 viruses unable to bind $\beta$-TrCP retain some degree of virulence suggesting the existence of other $\beta$-TrCP-independent functions, perhaps mediated by a second product identified in the $\operatorname{A} 49 \operatorname{ORF}(34,152)$. In addition to these proteins, several VACV proteins including K1 and A55 have been shown to act at the level of the NF- $\kappa \mathrm{B}$ heterodimer preventing their translocation or their normal processing $(35,43,153)$. Thus, they also have the potential to suppress STING-induced NF- $\mathrm{B}$ activation. Lastly, evidence exists that VACV downregulates NF- $\kappa$ B-dependent gene expression after p65 translocation by yet unidentified viral strategies (154).

\section{IMPLICATIONS FOR THE THERAPEUTIC USE OF VACV}

VACV-based therapeutics involve the use of VACV as a vaccine vector and oncolytic agent, as well as the use of VACV-derived proteins and peptides as biologicals. The development of VACV as a vaccine and for virotherapy holds promise and some forms of the virus are now in clinical studies, whereas the development of VACV-derived biologicals is at a much less advanced stage. VACV strain ACAM2000 (a derivative of Wyeth's Dryvax vaccine) and MVA (marketed as Jynneos) are approved by the USA Food and Drug Administration (FDA) for their use against smallpox and monkeypox, and various VACV strains have been engineered to carry heterologous antigens for diseases such as AIDS, malaria or tuberculosis amongst others (2). Enhancing immunogenicity and/or attenuating the virus remain desirable goals to increase VACV safety profile, elicit stronger immunological memory and reduce dosage and administration regimes. The discovery of DNA sensing pathways and their critical biological roles creates novel opportunities for the improvement of VACV as a therapeutic agent. The recognition of foreign incoming DNA in the cytosol triggers a potent immune and inflammatory reaction that includes IFN-I and IFNIII responses known to be beneficial for immune activation. Therefore, strategies aimed at increasing recognition of the VACV genome and boost intracellular DNA sensing signaling are likely to enhance vaccine efficacy and immunogenicity. These may include the deletion of immunomodulatory virulence factors from the virus or the co-administration of STING agonists. Evidence exists for the enhancement of immunogenicity and memory immunity upon removal of VACV immunomodulators [recently reviewed in (155)]. Some of these immunomodulators are listed above as viral DNA sensing antagonists. Therefore, this strategy seems logical to enhance IFN and cytokine production. An important aspect of consideration is whether removal of these viral immunomodulatory proteins is expected to impact on cGAMP levels. cGAMP triggers a STING-dependent, but cGASindependent induction of cytokines when transferred between cells. Horizontal transfer of cGAMP during infection therefore has the potential to boost and shape the adaptive response. 
Indeed, deletion of ECTV cGAMP nuclease vSchlafen led to a marked IFN-I signature in the draining lymph node and spleen that correlated with enhanced NK cell activation and survival to an otherwise lethal infection (99). Furthermore, studies have reported how the cGAS-STING axis promotes the generation of cytotoxic T cells (CTL) via the expression of IFN-I and the crosspresentation of antigens by dendritic cells (DC), in some cases after administration of exogenous cGAMP (156-159). Therefore, preventing the degradation of cGAMP by, for instance, removal of Poxin/B2 from VACV is likely to contribute favorably to the outcome of vaccination. A similar beneficial outcome may derive from the removal of VACV DNA-PK antagonists so DNA-PKmediated innate immunity responses are unleashed.

A second positive prospect from these studies is the value of STING agonists as adjuvants and anti-virals. Although smallpox was eradicated 40 years ago, the importance of compounds with anti-OPXV activity is increasing due to the emergence of zoonotic OPXV infections, particularly by MPXV. MPXV causes human monkeypox, an emerging zoonotic smallpox-like disease that has a mortality rate of $5-10 \%$ and has caused several outbreaks with hundreds of cases in Central and West Africa and outbound travelers $(160,161)$. At present, ST-246 (marketed as tecovirimat) is the only FDA-approved drug for the treatment of OPXV infections and although it has good activity range against multiple OPXV species including VARV (162164), alternative strategies are still desirable. Administration of exogenous cGAMP has been shown to elicit strong immune responses and protect mice against lethal ECTV infection (98, 99). This suggests that STING immunity is an attractive antiviral therapeutic target, although further experimentation is needed to determine the effects and specificity of cGAMP delivery pre- and post-infection as well as through different routes of inoculation.

A similar beneficial outcome in enhancing cGAS-STING signaling by either removal of viral immunosuppressive strategies or delivery of STING agonists might be expected in the context of oncolytic VACV. Oncolytic viruses are those that can selectively infect and/or grow in tumor cells leading to their destruction. VACV is a popular oncolytic virus for multiple reasons including its wide cell tropism and cytotoxicity, its ability to grow in hypoxic environments, the possibility for stable transgene expression and the fact that it does not integrate its DNA in the genome of the cell (165-167). Like tumor cells, VACV exploits multiple strategies to suppress cell death (168), some of which might be redundant with cancerous cells. However, whereas cancers tend to establish an immunosuppressive tumor microenvironment, VACV is immunogenic and is capable of altering the immune landscape, co-stimulating acquired anti-tumor immunity following replication within tumor tissues. In the case of immunogenic tumors, it has been reported that their recognition by the host immune system relies on STING-dependent cytosolic DNA sensing $(156,159)$. It has also been shown that intratumoral injection of MVA generated adaptive antitumor immunity in melanoma and colon cancer that was dependent on STING (169) and a GM-CSF (granulocytemacrophage colony-stimulating factor)-secreting vaccine showed increased anti-tumor efficacy when formulated with STING CDN agonists (170). In addition, susceptibility of certain cancers to viral oncolysis correlates with STING and STING signaling $(171,172)$. Collectively, these studies demonstrate the importance of the cGAS-cGAMP-STING axis in immunotherapy and offer scope for the improvement of oncolytic VACV and its therapeutic potential.

Finally, a number of human diseases have been connected with cytosolic DNA sensing. Mutations in several human genes result in the accumulation and mislocalisation of DNA molecules leading cGAS activation, and this is best exemplified in the form of the Aicardi-Goutières syndrome (AGS), a rare devastating disease characterized by systemic inflammation (173). The persistent stimulation of cGAS-STING signaling has also recently been associated with systemic lupus erythematosus (SLE) (174), a much more prevalent disease associated with IFNI dysregulation. Our increased knowledge on VACV antagonism of cytosolic DNA sensing may identify novel components or regulatory mechanisms of these cellular pathways and may reveal novel strategies to counteract the functions of these attractive therapeutic targets. For instance, detailed mechanistic and structural insights into VACV DNA sensing antagonists can allow the development of small molecule inhibitors mimicking the mode of action of the viral proteins. A proof of principle for these approaches is provided by the design of peptides deriving from VACV TLR inhibitors A46 and A52 $(175,176)$.

\section{CONCLUSIONS}

As our knowledge on nucleic acid immunity and inflammation expands it is becoming increasingly clear that the activation and regulation of intracellular DNA sensing has broad implications for human health and disease. VACV is a fantastic tool for discovery in human biology and virus pathogenesis as well as an important therapeutic tool. VACV has already proven pivotal in the discovery of cellular mechanisms for regulation of DNA sensing including uncovering the existence of viral and cellular cGAMP nucleases. VACV targets innate immune signaling at multiple levels and given the importance of DNA sensing for a cytosolic replicating virus it is likely that new viral inhibitors remain to be identified. Further research is also needed to address how VACV is sensed as the virion uncloaks and is recognized by cellular sensors. The identity and relative importance of these in the different cell types that are relevant for VACV infection and spread is also a necessary area of investigation. These findings need to be reciprocated in other poxviruses and can enlighten similar processes in viruses with similar biology such as the African Swine Fever virus and intracellular bacteria. Furthermore, many questions remain unanswered about how cells launch cell intrinsic defense mechanisms against VACV that involve recognition of its genome. Importantly, this knowledge is crucial to increasing the potential of VACV-based therapeutics both in the form of vaccines and oncolytic virus. 


\section{AUTHOR CONTRIBUTIONS}

Conceptualization and funding acquisition: CM. Writing: ME-J, MT, and CM. All authors contributed to the article and approved the submitted version.

\section{REFERENCES}

1. Esparza J, Schrick L, Damaso CR, Nitsche A. Equination (inoculation of horsepox): an early alternative to vaccination (inoculation of cowpox) and the potential role of horsepox virus in the origin of the smallpox vaccine. Vaccine. (2017) 35:7222-30. doi: 10.1016/j.vaccine.2017.11.003

2. Sanchez-Sampedro L, Perdiguero B, Mejias-Perez E, Garcia-Arriaza J, Di Pilato M, Esteban M. The evolution of poxvirus vaccines. Viruses. (2015) 7:1726-803. doi: 10.3390/v7041726

3. Goebel SJ, Johnson GP, Perkus ME, Davis SW, Winslow JP, Paoletti E. The complete DNA sequence of vaccinia virus. Virology. (1990) 179:247-66, 517-63. doi: 10.1016/0042-6822(90)90294-2

4. Volz A, Sutter G. Modified vaccinia virus ankara: history, value in basic research, and current perspectives for vaccine development. Adv Virus Res. (2017) 97:187-243. doi: 10.1016/bs.aivir.2016.07.001

5. Moss B. Poxviridae: the viruses and their replication. In: Knipe DM, editor. Fields Virology. Philadelphia, PA: Lippincott Williams and Wilkins (2007).

6. Condit RC, Moussatche N, Traktman P. In a nutshell: structure and assembly of the vaccinia virion. Adv Virus Res. (2006) 66:31-124. doi: 10.1016/S0065-3527(06)66002-8

7. Joklik WK. The Intracellular uncoating of poxvirus DNA. II. The molecular basis of the uncoating process. J Mol Biol. (1964) 8:277-88. doi: 10.1016/s0022-2836(64)80137-6

8. Kates JR, McAuslan BR. Messenger RNA synthesis by a coated viral genome. Proc Natl Acad Sci USA. (1967) 57:314-20. doi: 10.1073/pnas.57.2.314

9. Munyon W, Paoletti E, Grace JT Jr. RNA polymerase activity in purified infectious vaccinia virus. Proc Natl Acad Sci USA. (1967) 58:2280-7. doi: $10.1073 /$ pnas.58.6.2280

10. Woodson B. Vaccinia mRNA synthesis under conditions which prevent uncoating. Biochem Biophys Res Commun. (1967) 27:169-75. doi: 10.1016/s0006-291x(67)80057-3

11. Payne LG. Significance of extracellular enveloped virus in the in vitro and in vivo dissemination of vaccinia. J Gen Virol. (1980) 50:89-100. doi: 10.1099/0022-1317-50-1-89

12. Roberts KL, Smith GL. Vaccinia virus morphogenesis and dissemination. Trends Microbiol. (2008) 16:472-9. doi: 10.1016/j.tim.2008. 07.009

13. Hickman HD, Reynoso GV, Ngudiankama BF, Rubin EJ, Magadan JG, Cush SS, et al. Anatomically restricted synergistic antiviral activities of innate and adaptive immune cells in the skin. Cell Host Microbe. (2013) 13:155-68. doi: 10.1016/j.chom.2013.01.004

14. Parekh NJ, Krouse TE, Reider IE, Hobbs RP, Ward BM, Norbury CC. Type I interferon-dependent CCL4 is induced by a cGAS/STING pathway that bypasses viral inhibition and protects infected tissue, independent of viral burden. PLoS Pathog. (2019) 15:e1007778. doi: 10.1371/journal.ppat.10 07778

15. Gonzalez JM, Esteban M. A poxvirus Bcl-2-like gene family involved in regulation of host immune response: sequence similarity and evolutionary history. Virol J. (2010) 7:59. doi: 10.1186/1743-422X-7-59

16. Smith GL, Benfield CTO, Maluquer de Motes C, Mazzon M, Ember SWJ, Ferguson BJ, Sumner RP. Vaccinia virus immune evasion: mechanisms, virulence and immunogenicity. J Gen Virol. (2013) 94(Pt 11):2367-92. doi: 10.1099/vir.0.055921-0

17. Burles K, van Buuren N, Barry M. Ectromelia virus encodes a family of Ankyrin/F-box proteins that regulate NFkappaB. Virology. (2014) 468-70, 351-62. doi: 10.1016/j.virol.2014.08.030

18. Herbert MH, Squire CJ, Mercer AA. Poxviral ankyrin proteins. Viruses. (2015) 7:709-38. doi: 10.3390/v7020709

\section{FUNDING}

Work in the Maluquer Lab was supported by the UK Biotechnology and Biological Science Research Council (BBSRC grants BB/M003647/1 and BB/T006501/1).

19. Odon V, Georgana I, Holley J, Morata J, Maluquer de Motes C. Novel class of viral ankyrin proteins targeting the host E3 ubiquitin ligase cullin-2. J Virol. (2018) 92:e01374-18. doi: 10.1128/JVI.01374-18

20. Chung CS, Chen CH, Ho MY, Huang CY, Liao CL, Chang W. Vaccinia virus proteome: identification of proteins in vaccinia virus intracellular mature virion particles. J Virol. (2006) 80:2127-40. doi: 10.1128/JVI.80.5.2127-2140.2006

21. Resch W, Hixson KK, Moore RJ, Lipton MS, Moss B. Protein composition of the vaccinia virus mature virion. Virology. (2007) 358:233-47. doi: 10.1016/j.virol.2006.08.025

22. Doellinger J, Schaade L, Nitsche A. Comparison of the cowpox virus and vaccinia virus mature virion proteome: analysis of the species- and strain-specific proteome. PLoS ONE. (2015) 10:e0141527. doi: 10.1371/journal.pone.0141527

23. Goubau D, Deddouche S, Reis e Sousa C. Cytosolic sensing of viruses. Immunity. (2013) 38:855-69. doi: 10.1016/j.immuni.2013.05.007

24. Rathinam VA, Fitzgerald KA. Cytosolic surveillance and antiviral immunity. Curr Opin Virol. (2011) 1:455-62. doi: 10.1016/j.coviro.2011.11.004

25. Seet BT, Johnston JB, Brunetti CR, Barrett JW, Everett H, Cameron C, et al. Poxviruses and immune evasion. Annu Rev Immunol. (2003) 21:377-423. doi: 10.1146/annurev.immunol.21.120601.141049

26. Alcami A. Viral mimicry of cytokines, chemokines and their receptors. Nat Rev Immunol. (2003) 3:36-50 doi: 10.1038/nri980

27. Hernaez B, Alcami A. Virus-encoded cytokine and chemokine decoy receptors. Curr Opin Immunol. (2020) 66:50-56. doi: 10.1016/j.coi.2020.04.008

28. Fernandes-Alnemri T, Yu JW, Datta P, Wu J, Alnemri ES. AIM2 activates the inflammasome and cell death in response to cytoplasmic DNA. Nature. (2009) 458:509-13. doi: 10.1038/nature07710

29. Hornung V, Ablasser A, Charrel-Dennis M, Bauernfeind F, Horvath G, Caffrey DR, et al. AIM2 recognizes cytosolic dsDNA and forms a caspase-1-activating inflammasome with ASC. Nature. (2009) 458:514-8. doi: 10.1038/nature07725

30. Hemmi H, Takeuchi O, Kawai T, Kaisho T, Sato S, Sanjo H, et al. A Toll-like receptor recognizes bacterial DNA. Nature. (2000) 408:740-5. doi: $10.1038 / 35047123$

31. Kawai T, Akira S. The role of pattern-recognition receptors in innate immunity: update on toll-like receptors. Nat Immunol. (2010) 11:373-84. doi: 10.1038/ni.1863

32. Kawai T, Sato S, Ishii KJ, Coban C, Hemmi H, Yamamoto M, et al. Interferon-alpha induction through toll-like receptors involves a direct interaction of IRF7 with MyD88 and TRAF6. Nat Immunol. (2004) 5:1061-8. doi: $10.1038 /$ nil118

33. Mansur DS, Maluquer de Motes C, Unterholzner L, Sumner RP, Ferguson BJ, Ren H, et al. Poxvirus targeting of E3 ligase beta-TrCP by molecular mimicry: a mechanism to inhibit NF-kappaB activation and promote immune evasion and virulence. PLoS Pathog. (2013) 9:e1003183. doi: 10.1371/journal.ppat.1003183

34. Neidel S, Ren H, Torres A, Smith GL. NF-kappaB activation is a turn on for vaccinia virus phosphoprotein A49 to turn off NF-kappaB activation. Proc Natl Acad Sci USA. (2019) 116:5699-704. doi: 10.1073/pnas.1813504116

35. Pallett MA, Ren H, Zhang RY, Scutts SR, Gonzalez L, Zhu Z, et al. Vaccinia virus BBK E3 ligase adaptor A55 targets importin-dependent NF-kappaB activation and inhibits CD8(+) T-cell memory. J Virol. (2019) 93:e00051-19. doi: 10.1128/JVI.00051-19

36. Eaglesham JB, Pan Y, Kupper TS, Kranzusch PJ. Viral and metazoan poxins are cGAMP-specific nucleases that restrict cGAS-STING signalling. Nature. (2019) 566:259-63. doi: 10.1038/s41586-019-0928-6 
37. Graham SC, Bahar MW, Cooray S, Chen RA, Whalen DM, Abrescia NG, et al. Vaccinia virus proteins A52 and B14 Share a Bcl-2-like fold but have evolved to inhibit NF-kappaB rather than apoptosis. PLoS Pathog. (2008) 4:e1000128. doi: 10.1371/journal.ppat.1000128

38. Chen RA, Ryzhakov G, Cooray S, Randow F, Smith GL. Inhibition of IkappaB kinase by vaccinia virus virulence factor B14. PLoS Pathog. (2008) 4:e22. doi: 10.1371/journal.ppat.0040022

39. Scutts SR, Ember SW, Ren H, Ye C, Lovejoy CA, Mazzon M, et al. DNA-PK is targeted by multiple Vaccinia virus proteins to inhibit DNA sensing. Cell Rep. (2018) 25:1953-65 e4. doi: 10.1016/j.celrep.2018.10.034

40. Unterholzner L, Sumner RP, Baran M, Ren H, Mansur DS, Bourke NM, et al. Vaccinia virus protein C6 is a virulence factor that binds TBK-1 adaptor proteins and inhibits activation of IRF3 and IRF7. PLoS Pathog. (2011) 7:e1002247. doi: 10.1371/journal.ppat.1002247

41. Peters NE, Ferguson BJ, Mazzon M, Fahy AS, Krysztofinska E, ArribasBosacoma $\mathrm{R}$, et al. A mechanism for the inhibition of DNA-PKmediated DNA sensing by a virus. PLoS Pathog. (2013) 9:e1003649. doi: 10.1371/journal.ppat.1003649

42. Meade N, Furey C, Li H, Verma R, Chai Q, Rollins MG, et al. Poxviruses evade cytosolic sensing through disruption of an mTORC1-mTORC2 regulatory circuit. Cell. (2018) 174:1143-57 e17. doi: 10.1016/j.cell.2018.06.053

43. Shisler JL, Jin XL. The vaccinia virus K1L gene product inhibits host NFkappaB activation by preventing IkappaBalpha degradation. J Virol. (2004) 78:3553-60. doi: 10.1128/jvi.78.7.3553-3560.2004

44. Schroder M, Baran M, Bowie AG. Viral targeting of DEAD box protein 3 reveals its role in TBK1/IKKepsilon-mediated IRF activation. EMBO J. (2008) 27:2147-57. doi: 10.1038/emboj.2008.143

45. Maluquer de Motes C, Cooray S, Ren H, Almeida GM, McGourty K, Bahar MW, et al. Inhibition of apoptosis and NF-kappaB activation by vaccinia protein N1 occur via distinct binding surfaces and make different contributions to virulence. PLoS Pathog. (2011) 7:e1002430. doi: 10.1371/journal.ppat.1002430

46. DiPerna G, Stack J, Bowie AG, Boyd A, Kotwal G, Zhang Z, et al. Poxvirus protein N1L targets the I-kappaB kinase complex, inhibits signaling to NFkappaB by the tumor necrosis factor superfamily of receptors, and inhibits NF-kappaB and IRF3 signaling by toll-like receptors. J Biol Chem. (2004) 279:36570-8. doi: 10.1074/jbc.M400567200

47. Ferguson BJ, Benfield CTO, Ren H, Lee VH, Frazer GL, Strnadova P, et al. Vaccinia virus protein N2 is a nuclear IRF3 inhibitor that promotes virulence. J Gen Virol. (2013) 94(Pt 9):2070-81. doi: 10.1099/vir.0.054114-0

48. Ablasser A, Goldeck M, Cavlar T, Deimling T, Witte G, Rohl I, et al. cGAS produces a 2'-5'-linked cyclic dinucleotide second messenger that activates STING. Nature. (2013) 498:380-4. doi: 10.1038/nature12306

49. Diner EJ, Burdette DL, Wilson SC, Monroe KM, Kellenberger CA, Hyodo $\mathrm{M}$, et al. The innate immune DNA sensor cGAS produces a noncanonical cyclic dinucleotide that activates human STING. Cell Rep. (2013) 3:1355-61. doi: 10.1016/j.celrep.2013.05.009

50. Gao P, Ascano M, Wu Y, Barchet W, Gaffney BL, Zillinger T, et al. Cyclic $\left[\mathrm{G}\left(2^{\prime}, 5^{\prime}\right) \mathrm{pA}\left(3^{\prime}, 5^{\prime}\right) \mathrm{p}\right]$ is the metazoan second messenger produced by DNA-activated cyclic GMP-AMP synthase. Cell. (2013) 153:1094-107. doi: 10.1016/j.cell.2013.04.046

51. Sun L, Wu J, Du F, Chen X, Chen ZJ. Cyclic GMP-AMP synthase is a cytosolic DNA sensor that activates the type I interferon pathway. Science. (2013) 339:786-91. doi: 10.1126/science. 1232458

52. Wu J, Sun L, Chen X, Du F, Shi H, Chen C, et al. Cyclic GMP-AMP is an endogenous second messenger in innate immune signaling by cytosolic DNA. Science. (2013) 339:826-30. doi: 10.1126/science.1229963

53. Hornung V, Hartmann R, Ablasser A, Hopfner KP. OAS proteins and cGAS: unifying concepts in sensing and responding to cytosolic nucleic acids. Nat Rev Immunol. (2014) 14:521-8. doi: 10.1038/nri3719

54. Zhang X, Shi H, Wu J, Zhang X, Sun L, Chen C, et al. Cyclic GMPAMP containing mixed phosphodiester linkages is an endogenous high-affinity ligand for STING. Mol Cell. (2013) 51:226-35. doi: 10.1016/j.molcel.2013.05.022

55. Shang G, Zhang C, Chen ZJ, Bai XC, Zhang X. Cryo-EM structures of STING reveal its mechanism of activation by cyclic GMP-AMP. Nature. (2019) 567:389-93. doi: 10.1038/s41586-019-0998-5
56. Ablasser A, Chen ZJ. cGAS in action: expanding roles in immunity and inflammation. Science. (2019) 363:eaat8657. doi: 10.1126/science.aat8657

57. Ishikawa H, Barber GN. STING is an endoplasmic reticulum adaptor that facilitates innate immune signalling. Nature. (2008) 455:674-8. doi: $10.1038 /$ nature 07317

58. Ishikawa H, Ma Z, Barber GN. STING regulates intracellular DNA-mediated, type I interferon-dependent innate immunity. Nature. (2009) 461:788-92. doi: 10.1038/nature08476

59. Zhong B, Yang Y, Li S, Wang YY, Li Y, Diao F, et al. The adaptor protein MITA links virus-sensing receptors to IRF3 transcription factor activation. Immunity. (2008) 29:538-50. doi: 10.1016/j.immuni.2008.09.003

60. Burdette DL, Monroe KM, Sotelo-Troha K, Iwig JS, Eckert B, Hyodo M, et al. STING is a direct innate immune sensor of cyclic di-GMP. Nature. (2011) 478:515-8. doi: 10.1038/nature10429

61. Ablasser A, Schmid-Burgk JL, Hemmerling I, Horvath GL, Schmidt T, Latz $\mathrm{E}$, et al. Cell intrinsic immunity spreads to bystander cells via the intercellular transfer of cGAMP. Nature. (2013) 503:530-4. doi: 10.1038/nature12640

62. Luteijn RD, Zaver SA, Gowen BG, Wyman SK, Garelis NE, Onia L, et al. SLC19A1 transports immunoreactive cyclic dinucleotides. Nature. (2019) 573:434-8. doi: 10.1038/s41586-019-1553-0

63. Ritchie C, Cordova AF, Hess GT, Bassik MC, Li L. SLC19A1 is an importer of the immunotransmitter cGAMP. Mol Cell. (2019) 75:372-81 e5. doi: 10.1016/j.molcel.2019.05.006

64. Zhou C, Chen X, Planells-Cases R, Chu J, Wang L, Cao L, et al. Transfer of cGAMP into bystander cells via LRRC8 volume-regulated anion channels augments STING-mediated interferon responses and anti-viral immunity. Immunity. (2020) 52:767-81 e6. doi: 10.1016/j.immuni.2020.03.016

65. Mukai K, Konno H, Akiba T, Uemura T, Waguri S, Kobayashi T, et al. Activation of STING requires palmitoylation at the Golgi. Nat Commun. (2016) 7:11932. doi: 10.1038/ncomms11932

66. Tsuchida T, Zou J, Saitoh T, Kumar H, Abe T, Matsuura Y, et al. The ubiquitin ligase TRIM56 regulates innate immune responses to intracellular double-stranded DNA. Immunity. (2010) 33:765-6. doi: 10.1016/j.immuni.2010.10.013

67. Zhang J, Hu MM, Wang YY, Shu HB. TRIM32 protein modulates type I interferon induction and cellular antiviral response by targeting MITA/STING protein for K63-linked ubiquitination. J Biol Chem. (2012) 287:28646-55. doi: 10.1074/jbc.M112.362608

68. Wang Q, Liu X, Cui Y, Tang Y, Chen W, Li S, et al. The E3 ubiquitin ligase AMFR and INSIG1 bridge the activation of TBK1 kinase by modifying the adaptor STING. Immunity. (2014) 41:919-33. doi: 10.1016/j.immuni.2014.11.011

69. Liu S, Cai X, Wu J, Cong Q, Chen X, Li T, et al. Phosphorylation of innate immune adaptor proteins MAVS, STING, and TRIF induces IRF3 activation. Science. (2015) 347:2630. doi: 10.1126/science.aaa2630

70. Zhao B, Du F, Xu P, Shu C, Sankaran B, Bell SL, ET AL. A conserved PLPLRT/SD motif of STING mediates the recruitment and activation of TBK1. Nature. (2019) 569:718-722. doi: 10.1038/s41586-019-1228-x

71. Zhang C, Shang G, Gui X, Zhang X, Bai XC, Chen ZJ. Structural basis of STING binding with and phosphorylation by TBK1. Nature. (2019) 567:394-8. doi: 10.1038/s41586-019-1000-2

72. Ablasser A, Hur S. Regulation of cGAS- and RLR-mediated immunity to nucleic acids. Nat Immunol. (2020) 21:17-29. doi: 10.1038/s41590-019-0556-1

73. $\mathrm{Hu} \mathrm{MM}$, Shu HB. Innate immune response to cytoplasmic DNA: mechanisms and diseases. Annu Rev Immunol. (2020) 38:79-98. doi: 10.1146/annurev-immunol-070119-115052

74. Abe T, Barber GN. Cytosolic-DNA-mediated, STING-dependent proinflammatory gene induction necessitates canonical NFkappaB activation through TBK1. J Virol. (2014) 88:5328-41. doi: 10.1128/JVI.00037-14

75. Dunphy G, Flannery SM, Almine JF, Connolly DJ, Paulus C, Jonsson KL, ET AL. Non-canonical activation of the DNA sensing adaptor STING by ATM and IFI16 mediates NF-kappaB signaling after nuclear DNA damage. Mol Cell. (2018) 71:745-60 e5. doi: 10.1016/j.molcel.2018.07.034

76. Fang R, Wang C, Jiang Q, Lv M, Gao P, Yu X, et al. NEMO-IKKbeta are essential for IRF3 and NF-kappaB activation in the cGAS-STING Pathway. J Immunol. (2017) 199:3222-33. doi: 10.4049/jimmunol.1700699 
77. Balka KR, Louis C, Saunders TL, Smith AM, Calleja DJ, D'Silva DB, et al. TBK1 and IKKepsilon act redundantly to mediate STING-induced NF-kappaB responses in myeloid cells. Cell Rep. (2020) 31:107492. doi: 10.1016/j.celrep.2020.03.056

78. Oeckinghaus A, Ghosh S. The NF-kappaB family of transcription factors and its regulation. Cold Spring Harb Perspect Biol. (2009) 1:a000034. doi: 10.1101/cshperspect.a000034

79. Liu T, Zhang L, Joo D, Sun SC. NF-kappaB signaling in inflammation. Signal Transduct Target Ther. (2017) 2:17023. doi: 10.1038/sigtrans.2017.23

80. Giridharan S, Srinivasan M. Mechanisms of NF-kappaB p65 and strategies for therapeutic manipulation. J Inflamm Res. (2018) 11:407-19. doi: 10.2147/JIR.S140188

81. Takaoka A, Wang Z, Choi MK, Yanai H, Negishi H, Ban T, et al. DAI (DLM-1/ZBP1) is a cytosolic DNA sensor and an activator of innate immune response. Nature. (2007) 448:501-5. doi: 10.1038/nature06013

82. Ablasser A, Bauernfeind F, Hartmann G, Latz E, Fitzgerald KA, Hornung V. RIG-I-dependent sensing of poly(dA:dT) through the induction of an RNA polymerase III-transcribed RNA intermediate. Nat Immunol. (2009) 10:1065-72. doi: 10.1038/ni.1779

83. Chiu YH, Macmillan JB, Chen ZJ. RNA polymerase III detects cytosolic DNA and induces type I interferons through the RIG-I pathway. Cell. (2009) 138:576-91. doi: 10.1016/j.cell.2009.06.015

84. Unterholzner L, Keating SE, Baran M, Horan KA, Jensen SB, Sharma S, et al. IFI16 is an innate immune sensor for intracellular DNA. Nat Immunol. (2010) 11:997-1004. doi: 10.1038/ni.1932

85. Kim T, Pazhoor S, Bao M, Zhang Z, Hanabuchi S, Facchinetti V, et al. Aspartate-glutamate-alanine-histidine box motif (DEAH)/RNA helicase A helicases sense microbial DNA in human plasmacytoid dendritic cells. Proc Natl Acad Sci USA. (2010) 107:15181-6. doi: 10.1073/pnas.1006539107

86. Zhang Z, Yuan B, Bao M., Lu N, Kim T, Liu YJ. The helicase DDX41 senses intracellular DNA mediated by the adaptor STING in dendritic cells. Nat Immunol. (2011) 12:959-65. doi: 10.1038/ni.2091

87. Zhang X, Brann TW, Zhou M, Yang J, Oguariri RM, Lidie KB, et al. Cutting edge: Ku70 is a novel cytosolic DNA sensor that induces type III rather than type I IFN. J Immunol. (2011) 186:4541-5. doi: 10.4049/jimmunol.1003389

88. Ferguson BJ, Mansur DS, Peters NE, Ren H, Smith GL. DNA-PK is a DNA sensor for IRF-3-dependent innate immunity. Elife. (2012) 1:e00047. doi: 10.7554/eLife.00047

89. Kondo T, Kobayashi J, Saitoh T, Maruyama K, Ishii KJ, Barber GN, et al. DNA damage sensor MRE11 recognizes cytosolic double-stranded DNA and induces type I interferon by regulating STING trafficking. Proc Natl Acad Sci USA. (2013) 110:2969-74. doi: 10.1073/pnas.1222694110

90. Yoh M, Schneider M, Seifried J, Soonthornvacharin S, Akleh RE, Olivieri KC, et al. PQBP1 is a proximal sensor of the cGAS-dependent innate response to HIV-1. Cell. (2015) 161:1293-305. doi: 10.1016/j.cell.2015.04.050

91. Li Y, Chen R, Zhou Q, Xu Z, Li C, Wang S, et al. LSm14A is a processing body-associated sensor of viral nucleic acids that initiates cellular antiviral response in the early phase of viral infection. Proc Natl Acad Sci USA. (2012) 109:11770-5. doi: 10.1073/pnas.1203405109

92. Liu ZS, Cai H, Xue W, Wang M, Xia T, Li WJ, et al. G3BP1 promotes DNA binding and activation of cGAS. Nat Immunol. (2019) 20:18-28. doi: 10.1038/s41590-018-0262-4

93. Burleigh K, Maltbaek JH, Cambier S, Green R, Gale M Jr, James R. Human DNA-PK activates a STING-independent DNA sensing pathway. Sci Immunol. (2020) 5:4219. doi: 10.1126/sciimmunol.aba4219

94. Georgana I, Sumner RP, Towers GJ, Maluquer de Motes C. Virulent poxviruses inhibit DNA sensing by preventing STING activation. J Virol. (2018) 92:e02145-17. doi: 10.1128/JVI.02145-17

95. Haag SM, Gulen MF, Reymond L, Gibelin A, Abrami L, Decout A, et al. Targeting STING with covalent small-molecule inhibitors. Nature. (2018) 559:269-73. doi: 10.1038/s41586-018-0287-8

96. Schoggins JW, MacDuff DA, Imanaka N, Gainey MD, Shrestha B, Eitson JL, et al. Pan-viral specificity of IFN-induced genes reveals new roles for cGAS in innate immunity. Nature. (2014) 505:691-5. doi: 10.1038/nature12862

97. Cheng WY, He XB, Jia HJ, Chen GH, Jin QW, Long ZL, et al. The cGas-sting signaling pathway is required for the innate immune response against ectromelia virus. Front Immunol. (2018) 9:1297. doi: $10.3389 /$ fimmu.2018.01297
98. Wong EB, Montoya B, Ferez M, Stotesbury C, Sigal LJ. Resistance to ectromelia virus infection requires cGAS in bone marrow-derived cells which can be bypassed with cGAMP therapy. PLoS Pathog. (2019) 15:e1008239. doi: 10.1371/journal.ppat.1008239

99. Hernaez B, Alonso G, Georgana I, El-Jesr M, Martin R, Shair KHY, et al. Viral cGAMP nuclease reveals the essential role of DNA sensing in protection against acute lethal virus infection. Sci Adv. (2020) 6:eabb4565. doi: 10.1126/sciadv.abb4565

100. Antoine G, Scheiflinger F, Dorner F, Falkner FG. The complete genomic sequence of the modified vaccinia Ankara strain: comparison with other orthopoxviruses. Virology. (1998) 244:365-96. doi: 10.1006/viro.1998.9123

101. Delaloye J, Roger T, Steiner-Tardivel QG, Le Roy D, Knaup Reymond M, Akira $\mathrm{S}$, et al. Innate immune sensing of modified vaccinia virus Ankara (MVA) is mediated by TLR2-TLR6, MDA-5 and the NALP3 inflammasome. PLoS Pathog. (2009) 5:e1000480. doi: 10.1371/journal.ppat.1000480

102. Guerra S, Najera JL, Gonzalez JM, Lopez-Fernandez LA, Climent N, Gatell JM, et al. Distinct gene expression profiling after infection of immature human monocyte-derived dendritic cells by the attenuated poxvirus vectors MVA and NYVAC. J Virol. (2007) 81:8707-21. doi: 10.1128/JVI.00444-07

103. Barbalat R, Lau L, Locksley RM, Barton GM. Toll-like receptor 2 on inflammatory monocytes induces type I interferon in response to viral but not bacterial ligands. Nat Immunol. (2009) 10:1200-7. doi: 10.1038/ni.1792

104. Zhu J, Martinez J, Huang X, Yang Y. Innate immunity against vaccinia virus is mediated by TLR2 and requires TLR-independent production of IFN-beta. Blood. (2007) 109:619-25. doi: 10.1182/blood-2006-06-027136

105. Andrejeva J, Childs KS, Young DF, Carlos TS, Stock N, Goodbourn S, et al. The $\mathrm{V}$ proteins of paramyxoviruses bind the IFN-inducible RNA helicase, mda-5, and inhibit its activation of the IFN-beta promoter. Proc Natl Acad Sci USA. (2004) 101:17264-9. doi: 10.1073/pnas.0407639101

106. Kumar H, Kawai T, Kato H, Sato S, Takahashi K, Coban C, et al. Essential role of IPS-1 in innate immune responses against RNA viruses. J Exp Med. (2006) 203:1795-803. doi: 10.1084/jem.20060792

107. Dai P, Wang W, Cao H, Avogadri F, Dai L, Drexler I, et al. Modified vaccinia virus Ankara triggers type I IFN production in murine conventional dendritic cells via a cGAS/STING-mediated cytosolic DNA-sensing pathway. PLoS Pathog. (2014) 10:e1003989. doi: 10.1371/journal.ppat.1003989

108. Takahama M, Fukuda M, Ohbayashi N, Kozaki T, Misawa T, Okamoto $\mathrm{T}$, et al. The RAB2B-GARIL5 complex promotes cytosolic dnainduced innate immune responses. Cell Rep. (2017) 20:2944-54. doi: 10.1016/j.celrep.2017.08.085

109. Meade N, King M, Munger J, Walsh D. mTOR dysregulation by Vaccinia virus F17 controls multiple processes with varying roles in infection. J Virol. (2019) 93:e00784-19. doi: 10.1128/JVI.00784-19

110. Liu F, Niu Q, Fan X, Liu C, Zhang J, Wei Z, et al. Priming and activation of inflammasome by canarypox virus vector ALVAC via the cGAS/IFI16STING-type I IFN pathway and AIM2 sensor. J Immunol. (2017) 199:3293305. doi: 10.4049/jimmunol.1700698

111. Lieber MR. The mechanism of double-strand DNA break repair by the nonhomologous DNA end-joining pathway. Annu Rev Biochem. (2010) 79:181-211. doi: 10.1146/annurev.biochem.052308.093131

112. Morchikh M, Cribier A, Raffel R, Amraoui S, Cau J, Severac D, et al. HEXIM1 and NEAT1 Long non-coding RNA form a multi-subunit complex that regulates DNA-mediated innate immune response. Mol Cell. (2017) 67:387-99 e5. doi: 10.1016/j.molcel.2017.06.020

113. Almine JF, O'Hare CA, Dunphy G, Haga IR, Naik RJ, Atrih A, et al. IFI16 and cGAS cooperate in the activation of STING during DNA sensing in human keratinocytes. Nat Commun. (2017) 8:14392. doi: 10.1038/ncomms14392

114. Orzalli MH, Broekema NM, Diner BA, Hancks DC, Elde NC, Cristea IM, et al. cGAS-mediated stabilization of IFI16 promotes innate signaling during herpes simplex virus infection. Proc Natl Acad Sci USA. (2015) 112:E177381. doi: $10.1073 /$ pnas. 1424637112

115. Orzalli MH, DeLuca NA, Knipe DM. Nuclear IFI16 induction of IRF3 signaling during herpesviral infection and degradation of IFI16 by the viral ICP0 protein. Proc Natl Acad Sci USA. (2012) 109:E3008-17. doi: $10.1073 /$ pnas.1211302109

116. Fahy AS, Clark RH, Glyde EF, Smith GL. Vaccinia virus protein C16 acts intracellularly to modulate the host response and promote virulence. J Gen Virol. (2008) 89(Pt 10):2377-87. doi: 10.1099/vir.0.2008/004895-0 
117. Mazzon M, Peters NE, Loenarz C, Krysztofinska EM, Ember SW, Ferguson BJ, et al. A mechanism for induction of a hypoxic response by vaccinia virus. Proc Natl Acad Sci USA. (2013) 110:12444-9. doi: 10.1073/pnas.1302140110

118. Mazzon M, Castro C, Roberts LD, Griffin JL, Smith GL. A role for vaccinia virus protein C16 in reprogramming cellular energy metabolism. J Gen Virol. (2015) 96(Pt 2):395-407. doi: 10.1099/vir.0.069591-0

119. Ember SWJ, Ren H, Ferguson BJ, Smith GL. Vaccinia virus protein C4 inhibits NF-kappaB activation and promotes virus virulence. J Gen Virol. (2012) 93(Pt 10):2098-108. doi: 10.1099/vir.0.045070-0

120. Hiller G, Weber K. A phosphorylated basic vaccinia virion polypeptide of molecular weight 11,000 is exposed on the surface of mature particles and interacts with actin-containing cytoskeletal elements. J Virol. (1982) 44:647-57. doi: 10.1128/JVI.44.2.647-657.1982

121. Wickramasekera NT, Traktman P. Structure/function analysis of the vaccinia virus F18 phosphoprotein, an abundant core component required for virion maturation and infectivity. J Virol. (2010) 84:6846-60. doi: 10.1128/JVI.00399-10

122. Zhang YF, Moss B. Vaccinia virus morphogenesis is interrupted when expression of the gene encoding an 11-kilodalton phosphorylated protein is prevented by the Escherichia coli lac repressor. J Virol. (1991) 65:6101-10.

123. Kim J, Guan K. L. mTOR as a central hub of nutrient signalling and cell growth. Nat Cell Biol. (2019) 21:63-71. doi: 10.1038/s41556-018-0205-1

124. Liu GY, Sabatini DM. mTOR at the nexus of nutrition, growth, ageing and disease. Nat Rev Mol Cell Biol. (2020) 21:183-203. doi: 10.1038/s41580-019-0199-y

125. Seo GJ, Yang A, Tan B, Kim S, Liang Q, Choi Y, et al. Akt kinase-mediated checkpoint of cGAS DNA sensing pathway. Cell Rep. (2015) 13:440-9. doi: 10.1016/j.celrep.2015.09.007

126. Xu S, Ducroux A, Ponnurangam A, Vieyres G, Franz S, Musken M, et al. cGAS-mediated innate immunity spreads intercellularly through HIV-1 Env-induced membrane fusion sites. Cell Host Microbe. (2016) 20:443-57. doi: 10.1016/j.chom.2016.09.003

127. Bridgeman A, Maelfait J, Davenne T, Partridge T, Peng Y, Mayer A, etal. Viruses transfer the antiviral second messenger cGAMP between cells. Science. (2015) 349:1228-32. doi: 10.1126/science.aab3632

128. Gentili M, Kowal J, Tkach M, Satoh T, Lahaye X, Conrad C, et al. Transmission of innate immune signaling by packaging of cGAMP in viral particles. Science. (2015) 349:1232-6. doi: 10.1126/science.aab3628

129. Ryzhakov G, Randow F. SINTBAD, a novel component of innate antiviral immunity, shares a TBK1-binding domain with NAP1 and TANK. EMBO J. (2007) 26:3180-90. doi: 10.1038/sj.emboj.7601743

130. Stuart JH, Sumner RP, Lu Y, Snowden JS, Smith GL. Vaccinia virus protein C6 inhibits type I IFN signalling in the nucleus and binds to the transactivation domain of STAT2. PLoS Pathog. (2016) 12:e1005955. doi: 10.1371/journal.ppat.1005955

131. Lu Y, Stuart JH, Talbot-Cooper C, Agrawal-Singh S, Huntly B, Smid AI, et al. Histone deacetylase 4 promotes type I interferon signaling, restricts DNA viruses, and is degraded via vaccinia virus protein C6. Proc Natl Acad Sci USA. (2019) 116:11997-2006. doi: 10.1073/pnas.1816399116

132. Sumner RP, Ren H, Ferguson BJ, Smith GL. Increased attenuation but decreased immunogenicity by deletion of multiple vaccinia virus immunomodulators. Vaccine. (2016) 34:4827-34. doi: 10.1016/j.vaccine.2016.08.002

133. Sumner RP, Ren H, Smith GL. Deletion of immunomodulator C6 from vaccinia virus strain Western Reserve enhances virus immunogenicity and vaccine efficacy. J Gen Virol. (2013) 94(Pt 5):1121-6. doi: 10.1099/vir.0.049700-0

134. Garcia-Arriaza J, Arnaez P, Gomez CE, Sorzano CO, Esteban M. Improving adaptive and memory immune responses of an hiv/aids vaccine candidate mva-b by deletion of vaccinia virus genes (C6L and K7R) blocking interferon signaling pathways. PLoS ONE. (2013) 8:e66894. doi: 10.1371/journal.pone.0066894

135. Garcia-Arriaza J, Najera JL, Gomez CE, Tewabe N, Sorzano CO, Calandra T, et al. A candidate HIV/AIDS vaccine (MVA-B) lacking vaccinia virus gene C6L enhances memory HIV-1-specific T-cell responses. PLoS ONE. (2011) 6:e24244. doi: 10.1371/journal.pone.0024244

136. Marin MQ, Perez P, Gomez CE, Sorzano COS, Esteban M, GarciaArriaza J. Removal of the C6 vaccinia virus interferon-beta inhibitor in the hepatitis $\mathrm{C}$ vaccine candidate MVA-HCV elicited in mice high immunogenicity in spite of reduced host gene expression. Viruses. (2018) 10:414. doi: 10.3390/v10080414

137. Benfield CTO, Ren H, Lucas SJ, Bahsoun B, Smith GL. Vaccinia virus protein $\mathrm{K} 7$ is a virulence factor that alters the acute immune response to infection. J Gen Virol. (2013) 94(Pt 7):1647-57. doi: 10.1099/vir.0.05 2670-0

138. Soulat D, Burckstummer T, Westermayer S, Goncalves A, Bauch A, Stefanovic A, et al. The DEAD-box helicase DDX3X is a critical component of the TANK-binding kinase 1-dependent innate immune response. $E M B O$ J. (2008) 27:2135-46. doi: 10.1038/emboj.2008.126

139. Kalverda AP, Thompson GS, Vogel A, Schroder M, Bowie AG, Khan AR, et al. Poxvirus K7 protein adopts a Bcl-2 fold: biochemical mapping of its interactions with human DEAD box RNA helicase DDX3. J Mol Biol. (2009) 385:843-53. doi: 10.1016/j.jmb.2008.09.048

140. Garcia-Arriaza J, Gomez CE, Sorzano CO, Esteban M. Deletion of the vaccinia virus N2L gene encoding an inhibitor of IRF3 improves the immunogenicity of modified vaccinia virus Ankara expressing HIV-1 antigens. J Virol. (2014) 88:3392-410. doi: 10.1128/JVI.02 723-13

141. Chen RA, Jacobs N, Smith GL. Vaccinia virus strain Western Reserve protein B14 is an intracellular virulence factor. J Gen Virol. (2006) 87(Pt 6):1451-8. doi: 10.1099/vir.0.81736-0

142. Tang Q, Chakraborty S, Xu G. Mechanism of vaccinia viral protein B14mediated inhibition of IkappaB kinase beta activation. J Biol Chem. (2018) 293:10344-52. doi: 10.1074/jbc.RA118.002817

143. Benfield CT, Mansur DS, McCoy LE, Ferguson BJ, Bahar MW, Oldring AP, et al. Mapping the IkappaB kinase beta (IKKbeta)-binding interface of the B14 protein, a vaccinia virus inhibitor of IKKbeta-mediated activation of nuclear factor kappaB. J Biol Chem. (2011) 286:20727-35. doi: 10.1074/jbc.M111.231381

144. Torres AA, Albarnaz JD, Bonjardim CA, Smith GL. Multiple Bcl-2 family immunomodulators from vaccinia virus regulate MAPK/AP-1 activation. $J$ Gen Virol. (2016) 97:2346-51. doi: 10.1099/jgv.0.000525

145. McCoy LE, Fahy AS, Chen RA, Smith GL. Mutations in modified virus Ankara protein 183 render it a non-functional counterpart of B14, an inhibitor of nuclear factor kappaB activation. J Gen Virol. (2010) 91(Pt 9):2216-20. doi: 10.1099/vir.0.022343-0

146. Cooray S, Bahar MW, Abrescia NG, McVey CE, Bartlett NW, Chen RA, et al. Functional and structural studies of the vaccinia virus virulence factor N1 reveal a Bcl-2-like anti-apoptotic protein. J Gen Virol. (2007) 88(Pt 6):1656-66. doi: 10.1099/vir.0.82772-0

147. Veyer DL, Maluquer de Motes C, Sumner RP, Ludwig L, Johnson BF, Smith GL. Analysis of the anti-apoptotic activity of four vaccinia virus proteins demonstrates that $\mathrm{B} 13$ is the most potent inhibitor in isolation and during viral infection. J Gen Virol. (2014) 95(Pt 12):2757-68. doi: 10.1099/vir.0.068833-0

148. Ren H, Ferguson BJ, Maluquer de Motes C, Sumner RP, Harman LE, Smith GL. Enhancement of CD8 $(+)$ T-cell memory by removal of a vaccinia virus nuclear factor-kappaB inhibitor. Immunology. (2015) 145:34-49. doi: 10.1111/imm. 12422

149. Maluquer de Motes C, Schiffner T, Sumner RP, Smith GL. Vaccinia virus virulence factor $\mathrm{N} 1$ can be ubiquitylated on multiple lysine residues. J Gen Virol. (2014) 95(Pt 9):2038-49. doi: 10.1099/vir.0.065664-0

150. Neidel S, Maluquer de Motes C, Mansur DS, Strnadova P, Smith GL, Graham SC. Vaccinia virus protein A49 is an unexpected member of the Bcell Lymphoma (Bcl)-2 protein family. J Biol Chem. (2015) 290:5991-6002. doi: $10.1074 /$ jbc.M114.624650

151. Maluquer de Motes C, Smith GL. Vaccinia virus protein A49 activates Wnt signalling by targetting the E3 ligase beta-TrCP. J Gen Virol. (2017) 98:3086-92. doi: 10.1099/jgv.0.000946

152. Neidel S, Torres AA, Ren H, Smith GL. Leaky scanning translation generates a second A49 protein that contributes to vaccinia virus virulence. J Gen Virol. (2020) 10: 533-41. doi: 10.1099/jgv.0.001386

153. Bravo Cruz AG, Shisler JL. Vaccinia virus K1 ankyrin repeat protein inhibits NF-kappaB activation by preventing RelA acetylation. J Gen Virol. (2016) 97:2691-702. doi: 10.1099/jgv.0.000576 
154. Sumner RP, Maluquer de Motes C, Veyer DL, Smith GL. Vaccinia virus inhibits NF-kappaB-dependent gene expression downstream of p65 translocation. J Virol. (2014) 88:3092-102. doi: 10.1128/JVI.02627-13

155. Albarnaz JD, Torres AA, Smith GL. Modulating vaccinia virus immunomodulators to improve immunological memory. Viruses. (2018) 10:101. doi: 10.3390/v10030101

156. Deng L, Liang $\mathrm{H}, \mathrm{Xu} \mathrm{M}$, Yang $\mathrm{X}$, Burnette $\mathrm{B}$, Arina $\mathrm{A}$, et al. STING-Dependent cytosolic DNA sensing promotes radiation-induced type I interferon-dependent antitumor immunity in immunogenic tumors. Immunity. (2014) 41:843-52. doi: 10.1016/j.immuni.2014.10.019

157. Li T, Cheng H, Yuan H, Xu Q, Shu C, Zhang Y, et al. Antitumor activity of cGAMP via stimulation of cGAS-cGAMP-STING-IRF3 mediated innate immune response. Sci Rep. (2016) 6:19049. doi: 10.1038/srep19049

158. Wang H, Hu S, Chen X, Shi H, Chen C, Sun L, et al. cGAS is essential for the antitumor effect of immune checkpoint blockade. Proc Natl Acad Sci USA. (2017) 114:1637-42. doi: 10.1073/pnas.1621363114

159. Woo SR, Fuertes MB, Corrales L, Spranger S, Furdyna MJ, Leung MY, et al. STING-dependent cytosolic DNA sensing mediates innate immune recognition of immunogenic tumors. Immunity. (2014) 41:830-42. doi: 10.1016/j.immuni.2014.10.017

160. Rezza G. Emergence of human monkeypox in West Africa. Lancet Infect Dis. (2019) 19:797-9. doi: 10.1016/S1473-3099(19)30281-6

161. Sklenovska N, Van Ranst M. Emergence of monkeypox as the most important orthopoxvirus infection in humans. Front Public Health. (2018) 6:241. doi: 10.3389/fpubh.2018.00241

162. Jordan R, Leeds JM, Tyavanagimatt S, Hruby DE. Development of ST246(R) for treatment of poxvirus infections. Viruses. (2010) 2:2409-35. doi: 10.3390/v2112409

163. Mucker EM, Goff AJ, Shamblin JD, Grosenbach DW, Damon IK, Mehal JM, et al. Efficacy of tecovirimat (ST-246) in nonhuman primates infected with variola virus (Smallpox). Antimicrob Agents Chemother. (2013) 57:624653. doi: 10.1128/AAC.00977-13

164. Grosenbach DW, Honeychurch K, Rose EA, Chinsangaram J, Frimm A, Maiti B, et al. Oral tecovirimat for the treatment of smallpox. $N$ Engl J Med. (2018) 379:44-53. doi: 10.1056/NEJMoa1705688

165. Thorne S. H. Immunotherapeutic potential of oncolytic vaccinia virus. Immunol Res. (2011) 50:286-93. doi: 10.1007/s12026-011-8211-4

166. Chan WM, McFadden G. Oncolytic poxviruses. Annu Rev Virol. (2014) 1:119-141. doi: 10.1146/annurev-virology-031413-085442

167. Guo ZS, Lu B, Guo Z, Giehl E, Feist M, Dai E, et al. Vaccinia virus-mediated cancer immunotherapy: cancer vaccines and oncolytics. I Immunother Cancer. (2019) 7:6. doi: 10.1186/s40425-018-0495-7

168. Veyer DL, Carrara G, Maluquer de Motes C, Smith G. L. Vaccinia virus evasion of regulated cell death. Immunol Lett. (2017) 186:68-80. doi: 10.1016/j.imlet.2017.03.015
169. Dai P, Wang W, Yang N, Serna-Tamayo C, Ricca JM, Zamarin D, et al. Intratumoral delivery of inactivated modified vaccinia virus Ankara (iMVA) induces systemic antitumor immunity via STING and Batf3-dependent dendritic cells. Sci Immunol. (2017) 2:eaal1713. doi: 10.1126/sciimmunol.aal1713

170. Fu J, Kanne DB, Leong M, Glickman LH, McWhirter SM, Lemmens E, et al. STING agonist formulated cancer vaccines can cure established tumors resistant to PD-1 blockade. Sci Transl Med. (2015) 7:283ra52. doi: 10.1126/scitranslmed.aaa4306

171. Xia T, Konno H, Ahn J, Barber GN. Deregulation of STING signaling in colorectal carcinoma constrains dna damage responses and correlates with tumorigenesis. Cell Rep. (2016) 14:282-97. doi: 10.1016/j.celrep.2015.12.029

172. Xia T, Konno H, Barber GN. Recurrent loss of STING signaling in melanoma correlates with susceptibility to viral oncolysis. Cancer Res. (2016) 76:674759. doi: 10.1158/0008-5472.CAN-16-1404

173. Rice GI, Forte GM, Szynkiewicz M, Chase DS, Aeby A, Abdel-Hamid MS, et al. Assessment of interferon-related biomarkers in Aicardi-Goutieres syndrome associated with mutations in TREX1, RNASEH2A, RNASEH2B, RNASEH2C, SAMHD1, and ADAR: a case-control study. Lancet Neurol. (2013) 12:1159-69. doi: 10.1016/S1474-4422(13)70258-8

174. An J, Durcan L, Karr RM, Briggs TA, Rice GI, Teal TH, et al. Expression of cyclic GMP-AMP synthase in patients with systemic lupus erythematosus. Arthritis Rheumatol. (2017) 69:800-807. doi: 10.1002/art.40002

175. Lysakova-Devine T, Keogh B, Harrington B, Nagpal K, Halle A, Golenbock DT, et al. Viral inhibitory peptide of TLR4, a peptide derived from vaccinia protein A46, specifically inhibits TLR4 by directly targeting MyD88 adaptorlike and TRIF-related adaptor molecule. J Immunol. (2010) 185:4261-71. doi: 10.4049/jimmunol.1002013

176. McCoy SL, Kurtz SE, Macarthur CJ, Trune DR, Hefeneider SH. Identification of a peptide derived from vaccinia virus A52R protein that inhibits cytokine secretion in response to TLR-dependent signaling and reduces in vivo bacterial-induced inflammation. J Immunol. (2005) 174:3006-14. doi: 10.4049/jimmunol.174.5.3006

Conflict of Interest: The authors declare that the research was conducted in the absence of any commercial or financial relationships that could be construed as a potential conflict of interest.

Copyright (c) 2020 El-Jesr, Teir and Maluquer de Motes. This is an open-access article distributed under the terms of the Creative Commons Attribution License (CC BY). The use, distribution or reproduction in other forums is permitted, provided the original author(s) and the copyright owner(s) are credited and that the original publication in this journal is cited, in accordance with accepted academic practice. No use, distribution or reproduction is permitted which does not comply with these terms. 